\title{
STUDIES AND RESEARCH ON THE CONTROL OF THE RESIDUAL GAS LEAKS IN A CASTING METAL PARTS WORKSHOP
}

\author{
Mircea Viorel DRAGAN, Beatrice Daniela TUDOR \\ "Dunarea de Jos" University of Galati, Romania \\ e-mail: beatrice.tudor@ugal.ro
}

\begin{abstract}
The paper presents an analysis, regarding the control of the possible dangerous leaks of carbon monoxide, in this type of spaces, destined for the casting of the metal parts. These carbon monoxide leaks can occur mainly in the metal alloy making sector, which is to be cast into parts. The direct measurements were made especially in this working point, within the technological process, in different phases of the alloys elaboration process, but also during the time, when the workshop, was without production activity. The measurements were made with the help of the Fluke 975 Anemometer device, the results obtained being compared with the legislation in force, regarding safety and health at work.
\end{abstract}

KEYWORDS: dangerous gas leaks, alloy making, ventilation

\section{Introduction}

Environmental pollution is a reality today, it is found both in industrial areas and in urban settlements (to a lesser extent in rural areas). If natural pollution cannot be predicted, and in this context, only to a small extent can it be controlled, artificial pollution is induced by human activity (regardless of the type of activity undertaken), and depends only on us, to limiting the effects for the air water - soil [1].

Steel is a ubiquitous material in our daily lives, it is a $100 \%$ durable and recyclable material. No matter how much steel is recycled, it remains just as strong and durable [2, 3].

There are a number of new, modern processes for the manufacture of steel, which are in operation in industrial practice. The technological advances made in recent years have had as their main goal, the minimization of electricity consumption, and maximize energy efficiency in the manufacturing process.

During these activities, greenhouse gas emissions occur due to the following causes:

- chemical processes that take place in the production of steel;

- burning fuel for technological purposes, or for heating workspaces.

The process of elaboration and casting of steels, in electric arc furnaces, is one of the determining factors for the formation of gas and dust emissions.
The process of elaboration of steels in electric arc furnaces is based on physico-chemical processes, which take place at high temperatures, ensuring, based on specific technological instructions, the obtaining of steels, in the prescribed composition and quality.

The raw material used is scrap iron, and the main auxiliary materials are: iron ores, lime, dolomite, ferroalloys, coke, fluorine. The melting of the metal charge is done by means of the electric arc, formed between the electrodes of the electric furnace and the charge [4].

The process of making steel in electric arc furnaces includes several technological stages, characterized by technological operations which must be performed:

- adjustment (hot oven repairs - shotcreting);

- loading (operations of handling and loading of raw materials in these furnaces);

- melting (melting of the load, use of oxygen, oxy - gas burners);

- oxidation (insufflation of oxygen, evacuation of oxidizing slag);

- refining - deoxidation and alloying (addition of materials with deoxidizing action and alloying);

- evacuation (slag evacuation and steel evacuation, respectively).

In the current stage of technological development of the steel industry, the modernized electric furnace, transformed into a melting machine, transfers the refining - refining operations, in metallurgy aggregates in the pot, but here too, the 
mechanisms for forming gas and dust emissions are similar $[5,6]$.

Due to the physico-chemical processes, which take place at high temperatures, the elaboration is accompanied by the intense formation of gases, which contain an appreciable amount of dust.

The phenomenon is specific to all the mentioned technological stages, but especially to the melting and oxidation periods.

The amount of gas and dust emissions is directly proportional to the intensity of the physico-chemical processes, in the metal bath, and in the working space of the furnace, and depends on the specific periods of the elaboration process, presented below.

During the melting period:

- a brown smoke is emitted, due to the oxidation of metal vapours, which is emitted from the area of the electric arcs of the furnaces, where the temperature is much higher than their evaporation temperature;

- gas emissions are due to the oxidation of carbon in the area of the electric arc, where the temperature of the metal is maximum, and the burning of oils that contaminate the load, when during of the melting the load collapses.

Quantitatively, dust and gas emissions are variable, being influenced by two categories of factors:

a) technological factors:

- supply intensity and voltage of the furnace;

- how to intensify the melting (use of oxygen, oxy-gas burners);

- compactness of the load;

- the steel brand being developed;

b) random factors:

- unforeseen collapse of the load due to uneven melting;

- short circuits between the charge and the electrodes;

- damage to the electrodes.

During the oxidation period:

- gaseous emissions, in particular carbon oxides, because, due to the use of gaseous oxygen, decarburization occurs at high speed;

- a dense brown smoke is emitted, due to the vaporization of the metals, explainable by the fact that the decarburization process is accompanied by an intense release of heat, which determines the increase of the metal bath temperature, in the reaction zone, above the vaporization temperature of some metals dissolved in it; also, when the $\mathrm{CO}$ bubbles float and come out of the metal bath, on its entire surface, a mechanical extraction of the metal and slag particles takes place, which are entrained by the gas flow.

From a quantitative point of view, this is the stage in which the gas and dust emissions are maximum (usually the gas emissions from this period exceed by $20 \%$ the gas emissions from the melting period).

Taking samples for gas measurement can be performed either in the form of a network measurement or on point. Taking samples at a measuring point, in the measuring plane, means that the chosen measuring point is representative of the entire measuring cross section [7-9].

\section{Experimental results}

In the case of installations which operate in unchanging conditions, at least three discontinuous measurements are performed, in the case of a longterm normal operation, with maximum emission, and at least one more measurement, in the case of operating situations which repeats regularly, and aims at an oscillating emission behaviour.

In the case of installations whose operating conditions undergo temporal changes, sufficient measurements are made, but at least 6 , in the case of operating conditions which can lead to maximum emissions.

The duration of a discontinuous measurement must not exceed half an hour; measured values are noted as values/half an hour. The appliance also determines the temperature in the combustion zone, where the measurements are made.

The verification is performed in two measurement plans, at the beginning and at the end of the elaboration. This device measures the percentage of heat by convection, and the heat of radiation is not taken into account.

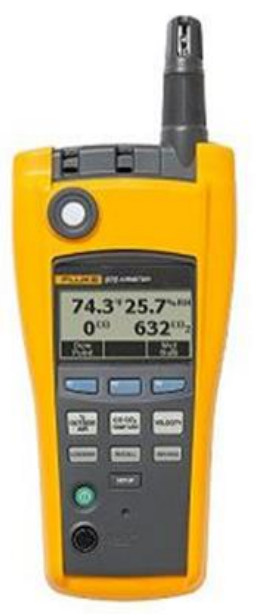

Fig. 1. Fluke 975 Anemometer

The experimental determinations were made in a workshop for casting metal parts, in 2 working points, respectively in the steel making area, in the electric arc furnace (point 1), and in the non-ferrous alloy 
making area, in the flame furnace (point 2). Determinations were made, and while the production activity was interrupted. The measurements were made at 10 minutes, during the operation of the workshop, in a time interval of 8 hours, during a working day.

In order to be able to describe a gas flow as clearly as possible, it is necessary to follow the following parameters of waste gases, which can be considered marginal conditions for waste gases:

- waste gas density;

- humidity;

- flow rate and static pressure;
- temperature [10].

The inspection instrument, used for complete air quality testing, is the Fluke 975 Anemometer, which combines five air monitoring instruments into a single, robust and easy-to-use instrument. The Fluke 975 is used to verify the efficient operation of heating, ventilation and air conditioning systems, and to test for hazardous carbon monoxide leaks in all types of buildings (Fig. 1).

The determined values were centralized in table 1 , and compare with the legislation in force, regarding the occupational exposure to chemical agents, according to GD. Nr. 1218/2006 [11-13].

Table 1. Average values of the determined parameters

\begin{tabular}{|c|c|c|c|c|}
\hline Working point & Temperature ${ }^{\circ} \mathrm{C}$ & $\begin{array}{c}\mathrm{CO}_{2} \mathrm{ppm} \\
\text { (average at } 8 \text { hours) }\end{array}$ & $\begin{array}{c}\mathrm{CO} \text { ppm } \\
\text { (average at } 8 \text { hours) }\end{array}$ & RH \% \\
\hline 1 & 122.3 & 866 & 1.03 & 28.5 \\
\hline 2 & 222 & 736 & 2.02 & 12.8 \\
\hline 3 & 20 & 18.3 & 0 & 9.4 \\
\hline
\end{tabular}

*1-Electric arc oven; 2-Oven with flame; 3-Area without production activity

Concentrations of chemicals in the air are usually measured as the mass of chemicals (milligrams, micrograms, nanograms or picograms) per volume of air (cubic meters or cubic feet). Concentrations can also be expressed as parts per million (ppm) or parts per billion (ppb) by using a conversion factor. This conversion factor is based on the molecular weight of the chemical and it is different for every chemical. The temperature of the atmosphere also has an influence on the calculation.
To convert $\mathrm{ppm}$ to $\mathrm{mg} / \mathrm{m}^{3}$ the next formula was used: concentration $\left(\mathrm{mg} / \mathrm{m}^{3}\right)=0.0409 \times$ concentration (ppm) x molecular weight.

Carbon monoxide [CO]: $\mathrm{M}=28.01 \mathrm{~g} / \mathrm{mol}$.

Carbon dioxide $\left[\mathrm{CO}_{2}\right]: \mathrm{M}=44.01 \mathrm{~g} / \mathrm{mol}$.

Where-M represents Molecular Weight.

Mandatory national occupational exposure limit values for chemical agents, according to GD. No. 1218/2006 (Table 2).

Table 2. Maximum allowable concentrations in the atmosphere of work areas according to the order of the Ministry of Health and Family no. 1218/2006

\begin{tabular}{|c|c|c|c|}
\hline \multirow{2}{*}{ Pollutant } & \multicolumn{2}{|c|}{ CMA mg/m } & \multirow{2}{*}{ The method used } \\
\cline { 2 - 3 } & Average (8 hours) & Maximum (15 min) & Analyzer \\
\hline Carbon monoxide $(\mathrm{CO})$ & 20 & 30 & Titrimetric \\
\hline Carbon dioxide $\left(\mathrm{CO}_{2}\right)$ & 9000 & - & \\
\hline
\end{tabular}

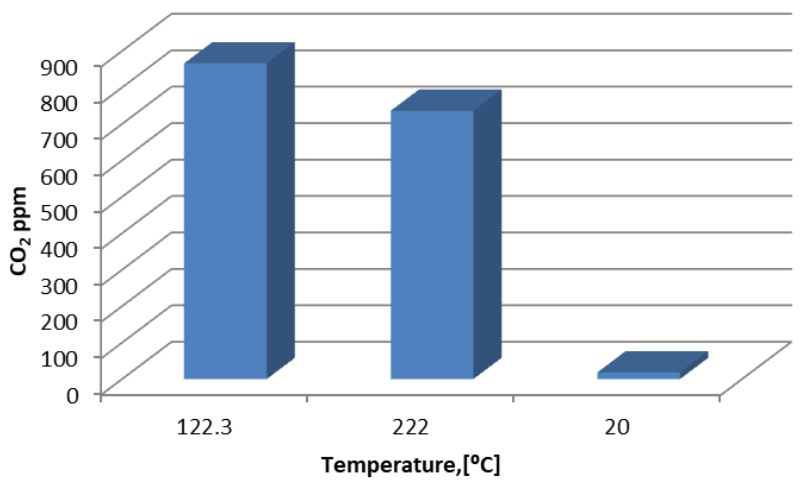

Fig. 2. Average $\mathrm{CO}_{2}$ values, determined in working points (1-Electric arc furnace; 2-Flame furnace; 3-Area without production activity) 


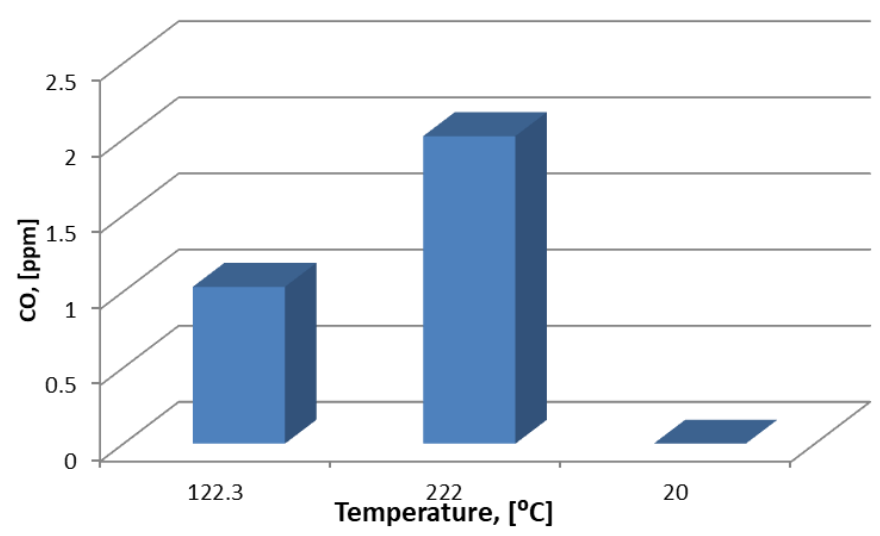

Fig. 3. Average CO values, determined in working points (1-Electric arc furnace; 2-Flame furnace; 3-Area without production activity)

As can be seen from the graphs above, the maximum values were determined in the flame furnace, especially during the melting and oxidation periods.

Although high values have been obtained, they fall within the limits prescribed by GD. No. $1218 / 2006$, regarding professional exposure to chemical agents.

The carbon dioxide $\left(\mathrm{CO}_{2}\right)$ content of the air is an indicator of ambient air quality, assuming that human respiration is the main source of $\mathrm{CO}_{2}$ emissions. Measuring instruments with $\mathrm{CO}_{2}$ sensors allow you to reliably control this important value: because, due to the decrease in ambient air quality (increasing the $\mathrm{CO}_{2}$ content in the air), performance decreases [11].

The highest determined value, for $\mathrm{CO}_{2}$, was detected in the working area of the electric arc furnace. In the flame oven, we have a lower value of $\mathrm{CO}_{2}$, determined at a higher temperature (Fig. 2).

When assessing ambient air quality by measuring the $\mathrm{CO}_{2}$ concentration and other parameters, the $\mathrm{CO}_{2}$ concentrations should not exceed $1000 \mathrm{ppm}$.
Carbon monoxide is colourless and odourless, and stops the absorption of oxygen by the blood, when inhaled too high a concentration. Breathing $\mathrm{CO}$ in a concentration of $700 \mathrm{ppm}$, in an enclosed space, leads to death in about 3 hours.

It is a suffocating, toxic gas, which arises from an incomplete combustion (oxidation) of carboncontaining substances. The most common sources of daily $\mathrm{CO}$ are: gasoline engines, gas ovens, heating systems, solid fuels such as wood and coal.

The maximum allowable concentration of carbon monoxide at work is $30 \mathrm{ppm}$ (parts per million). Carbon monoxide can accumulate very quickly, to a life-threatening extent, in enclosed and semi-enclosed spaces. A carbon monoxide detector allows reliable detection of this insidious gas [12].

The average of the carbon monoxide determinations, in all the monitored working points, is inscribed in the allowed values, according to the norms in force, regarding the air quality in closed working spaces, obtaining a maximum, in the working point, the flame furnace (Fig. 3).

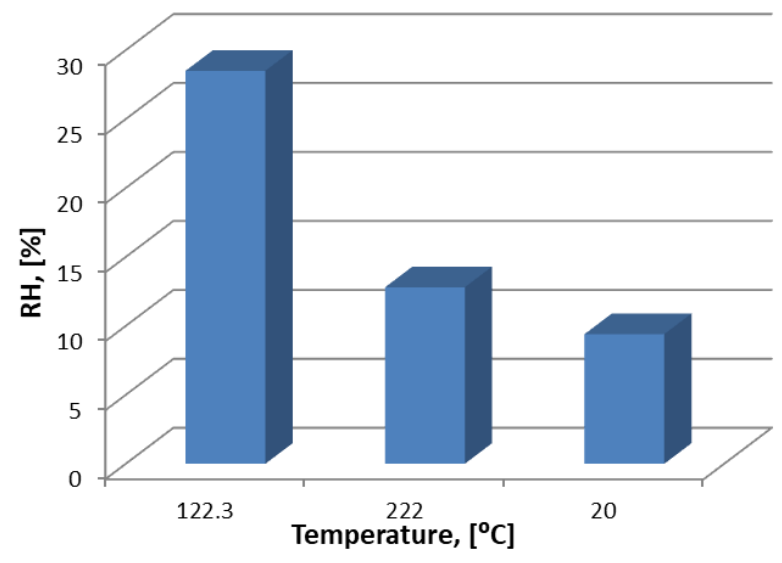

Fig. 4. Average humidity values, determined in working points (1-Electric arc furnace; 2-Flame furnace; 3-Area without production activity) 
The humidity formed in a room depends mainly on the following factors: moisture production in the room, air exchange with outside air, moisture absorption capacity by walls and furniture, transport of moisture by external construction components.

Parameters, air temperature, and relative humidity are important for planning, choosing, and installing ventilation systems, and air conditioning.

The humidity of the air decisively influences the feeling of comfort of the people in a room. The ideal ambient humidity is between 30 and $65 \%$. Of course, in addition to this, the temperature is also decisive. High air humidity can be extremely annoying in high temperatures [13].

For this reason, humidity measuring devices are generally equipped with humidity and temperature sensors.

Humidity values, determined in all work points, as well as in the workshop, when we do not have production activity, are within the norms regarding air quality, in closed industrial workspaces (Fig. 4).

\section{Conclusions}

The paper presents the data necessary to investigate the occupational exposure to noxious pollution, regarding the control of hazardous waste gas leaks, in a workshop for casting metal parts.

The evaluation involves the investigation of the working environment conditions (knowledge of technological processes, choice of noxious substances, air sampling, method used, interpretation of results, etc.).

In order to create conditions appropriate to the working environment, a series of technical and organizational measures are required as follows:

Organizational measures:

- training on the need to use work-specific protective equipment;

- periodic medical control, with the theme of detecting diseases that are manifested, or are about to be installed, in the respiratory system;
- making determinations for the air quality in the workplace atmosphere, with the periodicity required by law;

- appropriate signalling of risks at workplaces.

Technical measures:

- Acquisition of E.I.P. corresponding to the activity to be carried out according to the regulations in force.

- Identification and design / redesign of the working conditions, in accordance with the legislation in force regarding the minimum safety and health requirements for the workplaces.

\section{References}

[1]. Bălănescu Niculina, Melinte Ion, Nicolae A., Evaluarea riscului de mediu în metalurgie, Editura Printech, București, 2007.

[2]. Ameling D., Otelul - material inovativ, Stahl und Eisen, iunie 1999.

[3]. Boldin S. S., Ecologhiia liteinogo proizvodstva, BGTU, Rusia, 2001.

[4]. Predescu C., Echipamente și instalatii pentru ecologizarea sectoarelor metalurgice, Editura Bren, Bucureşti 1998.

[5]. Ciocănea A., Dezvoltarea socio-economică durabilă şi metabolismul sistemelor industriale, în vol. CNDD, Bucureşti, 2000.

[6]. Constantinescu D., Nicolae A., Aspect regarding the ecological balance for metallurgical processes, in Metalurgija, (Croatia), 2000, nr. 1.

[8]. European Commission, Integ. Pollution Preven. and Control (IPPC), Best Available Techniques Reference Document on the Production of Iron and Stell, Seville (Spain), 1999.

[9]. Ioana A., Nicolae A., Posibilităti de reducere a impactului cuptorului cu arc electric asupra mediului înconjurător, vol. CNMSM, Bucureşti, 2001.

[10]. Suciu M. V., Nicolae C., Stefanoiu R., Geanta V., Suciu V., Stan S., Tehnici de prevenire a poluarii la fabricarea tevilor de otel, Ed. Printech, Bucuresti, ISBN 978-973-718-963-9, 2008.

[11]. Consiliul Comunitatilor Europene, Directiva Consiliului din 28 iunie 1984 de combatere a poluarii aerului prin instalatile industriale, (84/360/EWG), 1984.

[12]. Consiliul Comunitatilor Europene, Directiva Consiliului 1999/13/EG din 11 martie 1999 referitoare la limitarea emisiilor de compusi organici volatili, care apar la anumite activitati si in anumite instalatii, cand sunt utilizati solventi organici, 1999.

[13]. ***, http://www.environment.gov.au/ - efect de sera, industrie, deseuri, probleme de mediu, managementul mediului, calitatea aerului si apei (en). 